\title{
National Space Activities: Modern Realities and Legal Challenges
}

\author{
Vasyl Semenyaka \\ Ph.D. in Law, Senior Researcher, V.M. Koretsky Institute of State \\ and Law of NAS of Ukraine \\ (Kyiv, Ukraine) \\ E-mail: v.semenyaka@ukr.net \\ https://orcid.org/0000-0002-1621-9694
}

\begin{abstract}
Semenyaka, Vasyl (2020) National Space Activities: Modern Realities and Legal Challenges. Advanced Space Law, Volume 5, 91-100. https://doi.org/10.29202/asl/2020/5/9
\end{abstract}

The article studies the current state of affairs in national space activities. The legal problems facing the space industry at the present stage, the mechanism of their solution are analyzed. The author highlights the crucial issue, which requires an immediate solution regarding the location of the launch site for domestic space objects. The special role of the State in ensuring the legal conditions for the development of national space activities, which should be carried out using good in law modern methods and means of public regulation, is determined. Nowadays, the legislation of Ukraine on space activities requires significant changes and additions, taking into account the new space realities and instruments for the development of public relations in the field of space exploration and use. The author argues that a strategy for the development of space activities in Ukraine, public administration of the space industry, as well as ensuring its restructuring require a substantial rethinking and improvement. The relevance of the legal framework for the creation and use of space defense and dual-use space technology in the interests of the national security and defense sector is underlined. The author argues that the Concept of Ukrainian law reform on space activities, including the legal rationale for choosing the optimal behavior model regarding the solution of complex legal problems based on modern space-legal doctrine and practice of space relations, should be developed.

Keywords: space law, space relations, space activity, launch site, launch vehicle, spacecraft.

Received: March 11, 2020; accepted: April 17, 2020

(C) Semenyaka, Vasyl, 2020 


\section{Introduction}

Ukraine occupies a worthy place in the global market for commercial space services and technologies. The leading areas of national space activities include the production and launch of launch vehicles for the delivery of payloads, such as spacecraft to the Earth's space orbit, the manufacture of systems and instruments for the control of launch vehicles and spacecraft. Domestic production infrastructure enables us to carry out the design, manufacture, and operation of world-class competitive launch vehicle products.

Since 1991, 165 space launches have been made with the use of Ukrainian-made launch vehicles (Zenit-3SLB, Zenit-3SL, Zenit-2, Cyclone-2, Cyclone-3, Dnipro) and foreign launch vehicles: American Antares and the European Vega, which are completed with domestic components (respectively, the basic design of the first stage and the upper stage marching engine) (Statistics, 2020). It was found that the record year for Ukraine was 2004, when the share of Ukrainian launches of space objects accounted for $13 \%$ of world space launches. Without exaggeration, the Ukrainian space program has something to be proud of.

However, since 2014, the situation in the space services market has changed dramatically for Ukraine. According to information and statistics, launches of Ukrainian launch vehicles have actually stopped. Only two launches were made using Zenit-3SLB launch vehicle $(2015,2017)$ from the Baikonur site within the Ground Launch project, three launch vehicles using the Dnipro $(2014,2015)$ from the launch site Yashyi and launch vehicle Zenit-3SL (2014) within the Sea Start project (Statistics, 2020). Only the international space projects Antares and Vega are fully implemented.

The current external and internal changes that have taken place in the country require to update systematically and structurally national space legislation and to bring it into line with new economic and legal realities. In order not to lose its place in the global space services market, the State should more actively apply the existing public legal instruments to create conditions for the development of space activities in the interests of the national economy, science, defense, and security.

In light of the challenges and threats to Ukraine's space industry, the legal issues of organizing and ensuring the further effective use of national space-rocket capabilities are relevant.

\section{Main material}

Space activities for launching a space launch system are carried out by Ukrainian entities operating in the space sector of the economy on the basis of external economic relations with foreign objects.

Predominantly, launches of Ukrainian launch vehicles were carried out in close cooperation with the Russian Federation using its Yasnyi launch base, launch sites of Plesetsk and Baikonur (Kazakhstan transferred Baikonur into the possession and use of the Russian Federation by 2050) (Treaty, 2004). It was a mutually beneficial Ukrainian-Russian space collaboration. However, as a result of Russia's occupation of the Autonomous Republic of Crimea (ARC), the seizure of the National Centre for Space Control and Testing in Yevpatoria, as well as military aggression in the territory of Donbas, cooperation between the States in the field of the creation and operation of rocket and space technology is de facto curtailed.

Therefore, one of the key problems of modern space industry development is that our State does not have its own launch site for launching a domestic launch vehicle. According to the global space market's data, Ukraine slows down its space launch operations. In 2019, 102 launch 
vehicles were launched from 16 launch sites of the world, and 433 spacecraft were launched into space (Zheleznyakov, 2019). However, Ukraine has not launched any Ukrainian launch vehicle, which causes the loss of competitive positions in this segment of the commercial space launch services market. Meanwhile, the number of countries that search for quality, reliable and costeffective space launch services, especially in low Earth orbit, increases every year.

Our state had ambitious space plans to use the Ukrainian-Brazilian launch site, which had been constructed in the territory of Brazil within the framework of the joint space project of Ukraine and the Federal Republic of Brazil Alcantara Cyclone Space since 2006 (Treaty, 2003). It was planned to create a Cyclone-4 launch pad at Alcantara Launch Centre and provide services for national space programs as well as commercial launch service customers. Moreover, Ukraine provided funding for the development of the launch vehicle Cyclone-4, its components and assemblies, a comprehensive test, and preparation of the production base.

The first launches from this pre-equatorial launch site were due in late 2014. However, work on the launch site was suspended by the Brazilian side in 2013, and in 2015 the Brazilian Government unilaterally terminated an international agreement on the implementation of this project, and Brazil withdrew from the project (Order, 2017). Therefore, the implementation of this project has been terminated.

Since then, Ukraine has been searching for partners and a new launch site for Ukrainian launch vehicles on a rush basis. An alternative launch site to Russian one should be found as soon as possible, as the space launch system must work for the benefit of the State, its citizens.

However, the Space Strategy of Ukraine up to 2022 (Strategy, 2015) and the Government's Concept of public policy in the field of space activities for the period up to 2032 (Order, 2011) do not provide for the use of launch site to launch Ukrainian launch vehicles, despite unfulfilled plans to use the Ukrainian-Brazilian launch site. Unfortunately, the issue of the location to launch space objects is still not in any of the strategic documents of the space industry. However, it is very relevant for the development of the space industry and needs to be addressed.

It should be noted that the project of the National Target Scientific and Technical Space Program of Ukraine for 2019-2023 provides for the creation of spacecraft for national needs (Project, 2018). However, a logical question arises, "How should Ukraine ensure their launch into outer space?" Despite having our launch vehicle, we will actually be forced to become consumers of foreign space launch services.

Meanwhile, space activities require an immediate solution to this problem. For example, the options for the location of the space launch system in Australia (Kimberley), the USA (Cape Canaveral), Mexico, and Canada have been considered. As practice shows, launch sites are usually built on sparsely populated areas of the earth, where the likelihood of harm, especially to the population and environment, is minimal.

As a result of the investigations, the most effective and rational location was determined in the Canadian province of Nova Scotia (Analytical).

In 2017, a Memorandum of Understanding in the field of peaceful exploration and use of outer space was signed between the State Space Agency of Ukraine (SSA) and the Canadian Space Agency (Memorandum, 2018). The target of mutually beneficial Ukrainian-Canadian cooperation was the creation of a common space launch system. Moreover, such arrangements have specific forms. In 2018, contractual documents were signed on the construction of a private Ukrainian-Canadian space launch system to launch Ukrainian Cyclone-4M medium-lift class launch vehicles from the Canadian province of Nova Scotia. It uses the developments from the design of the Cyclone-4 space launch system. 
By now, permits and procedural approvals have been completed to construct the launch site. The direct conduct of construction works began at the end of 2019 without the involvement of the State budget. The main participants of the project were Ukrainian Yuzhnoye State Design Office, SE PA Yuzhmash, PJSC Hartron, and Canadian Maritime Launch Services Ltd. (Analytical).

At the same time, to ensure real freedom of national space activities, to empower Ukraine in the global space services market, domestic space groups discuss the possibility of building their Ukrainian launch site for launching space objects. Furthermore, the leading space enterprises in the space industry of Ukraine are simultaneously developing two projects for their location in the Kherson region. For example, Yuzhnoye SDO proposes to create a space launch system based on a lightweight launch vehicle Cyclone-1M for launching space objects into low Earth orbit (Treaty between, 2003). Also, SE PA Yuzhmash proposes the construction of a floating platform for space launches (The first, 2019). Therefore, the consolidation and coordination of their efforts to address the sustainable development of national space activities become essential. In this context, an important mission is given to the Ministry of Development of Economy, Trade, and Agriculture of Ukraine (Ministry of Economy) and the SSA to formulate and ensure the implementation of national space policy in this area.

An individual launch site is independent in access to outer space, including the moon and other celestial bodies. Ukrainian comprehensive space cooperation with Russia and Brazil have exposed extremely high political and economic risks, the probability of which is unpredictable.

However, it should be noted that the launch system is of high risk by its nature. Legal relations associated with possible launching of space objects from Ukraine shall be subject to the rule of international space law regarding the specificities of foreign legal liability for damage caused by space objects, since the State will have the legal status of the launching State.

According to Article VII of the Treaty on Principles Governing the Activities of States in the Exploration and Use of Outer Space, including the Moon and Other Celestial Bodies (Treaty, 1966), the launching State shall be liable for damage to another State Party to this Treaty, to its natural or juridical persons by space objects or their component parts on the Earth or in outer space, including the moon and other celestial bodies. That is, the subject of international legal relations, ultimately liable for damage to a third party by a space object on the Earth's surface or an aircraft in flight, is the launching State of the relevant space object. Therefore, the risk of international legal liability for the damage caused lies unconditionally on the launching State and not on the launch service operator as the launching entity.

However, the provisions of the Convention on International Liability for Damage Caused by Space Objects (hereinafter referred to as the Liability Convention) (Convention, 1971) do not provide for an upper limit for compensation for damage caused by space objects on the Earth's surface or aircraft in flight. Therefore, the corresponding damage is subject to full compensation by the State.

During the pre-launch and launch of space technology into orbit, business entities must take the necessary precautions to prevent technogenic incidents and disasters that may cause damage to the lives and health of individuals and damage to property of individuals and legal entities (victims). However, space liability risk insurance is an active civil law way of protecting the property interests of the State and of space entities (in particular, the launch service operator) due to the need to provide compensation for damage to life, health and property of victims in the process of space activity.

The provisions of international space law do not specify the specific legal mechanism of space liability insurance. The insurance protection is addressed at the level of national legislation. 
Paragraph 1 of part 1of Article 7 of the Law of Ukraine on Insurance (Law, 1996) provides for compulsory liability insurance for risks associated with the preparation for launching space technology at the launch site and its launching.

The Resolution of the Cabinet of Ministers of Ukraine "On approval of the procedures and rules of compulsory insurance in the field of space activity" (hereinafter - Procedure and Rules) (Resolution, 2010) provides for the procedure and rules for carrying out this type of compulsory liability insurance, the risk of policyholder's obligation to compensate losses caused by the object of space activity. According to the Procedure and Rules, compulsory liability insurance is carried out in Ukraine if a launch vehicle, spacecraft, boosters, and other space objects owned by Ukraine are used. That is, liability for damage caused only by objects of space activity, which are the property of Ukraine, is subject to compulsory insurance.

By this type of insurance, the insured is the SSA. In this case, victims are foreign States, third parties (legal and natural), whose life, health and/or property are damaged due to pre-launch, launch, and operations in orbit.

Insured risks are risks arising from the obligation of the policyholder to compensate for the damage caused by the space activity: 1) to an aircraft on the ground or in-flight; 2) to any other space object or persons or property on board such a space object in any place elsewhere than the Earth's surface. An insured event is, by the Liability Convention and/or in accordance with the law, the occurrence of an insured person' obligation to compensate the victim for the damage caused by the object of space activity as a source of increased danger.

The subject of the liability insurance contract is the property interests of the insured, which are not in contradiction of the law and related to the compensation of the insured for the damage caused to the life, health and/or property of the victim. Consequently, liability insurance is aimed at protecting the property interests of the insured against the losses that he may suffer as a result of third-party claims for compensation.

The sum insured shall be established in a compulsory insurance contract equivalent to 500 USD at the official exchange rate of the National Bank of Ukraine, established at the date of the insurance contract, per kilogram of the starting mass of the space object. And the amount of the insurance tariff is determined depending on the state of the object of space activity, the significant circumstances of the insurance risk, the term of the insurance treaty, the situation of the international insurance market, etc. Mandatory insurance has a maximum insurance rate of 2 percent of the sum insured (Regulation, 2010).

Therefore, the State ensures the protection of its property interests in the event of a binding relationship in relation to its absolute liability for damage caused to third parties. However, compulsory civil liability insurance of space entities other than the State is carried out on a voluntary basis by concluding a relevant insurance contract, since the Cabinet of Ministers of Ukraine has not defined the procedure and rules for its conduct, form of a standard contract, special licensing conditions of compulsory insurance, sums insured and maximum insurance rates or actual calculations.

Therefore, the implementation of potential launches of Ukrainian launch vehicles involves a set of political, technical, environmental and legal risks that require systematic analysis and expert assessment. However, the issue of own launch site faces the need to solve the problem of providing investment component of space activities, government and financing of space industry. Space activity is an extremely capital-intensive type of business that requires the accumulation of significant financial resources. Therefore, the analysis of the economic profitability of construction and use of the national launch site is also of importance. 
In the Ukrainian context, national space activities are financed from the budget within the framework of the National Target Scientific and Technical Space Programs, developed and approved by the Verkhovna Rada of Ukraine every five years (Law, 1996). However, what is planned for the program contradicts to what is actually coming into the space industry. Nowadays, its development is under-financed. This is probably one of the reasons why Ukraine does not operate any spacecraft. However, it has the necessary technological potential to create and use the space launch system that many countries dream of. It should be noted that our State does not use it properly to ensure the innovative development of the State. For example, Ukraine still purchases space services for Earth remote sensing, television broadcasting, mobile communications from foreign space partners.

In the current context, the consideration of global trends in space activities, based on the use of public-private partnership instruments in the field of space, is of particular importance. The legal space relationship between the National Aeronautics and Space Administration (NASA) and the US private enterprise SpaceX illustrates such a partnership. Unfortunately, this instrument has no practical application in the domestic space industry, since the legal framework for its formation and development are almost absent. Activities related to the development, testing, production, and operation of launch vehicles and their space launches were the sole responsibility of Stateowned enterprises and organizations (Law, 1991). That is, the State monopolized these types of national space activities.

Nowadays, the State has decided to engage private entities in this type of space business, eliminating a discriminatory approach to economic entities. In turn, the removal of restrictions on the right to conduct space activities by its standards and organizational and legal forms of management should encourage the development of national space activities.

However, the rules of the current space legislation of Ukraine do not contain a stimulating legal effect. The provision of Article 10 of the Law of Ukraine "On Space Activity" requires obtaining the permits by economic entities for carrying out space activities, such as:

a) testing (other than computer-based) launch vehicles, including their units and components and spacecraft;

b) launches of the launch vehicle and/or spacecraft;

c) control of spacecraft in Earth orbit or outer space;

d) the return of spacecraft and/or their rotating components from Earth's orbit or outer space to Earth.

Therefore, the motivation of entities to engage in space activities requires liberalizing the legal regulation of space activities by abolishing the licensing mechanism for its implementation, since this instrument of public legal regulation is unjustified. It lacks the necessary balance of space operators' interests and the State.

Excessive direct influence of the State on space activities does not contribute to the sustainable development of scientific space research, creation and application of space technology, use of outer space. In this area, it is advisable to use alternative legal means to ensure compliance of national space activities with the standards and principles of international space law, for example, to increase the requirements for the quality of space works (services, goods), the introduction of certification of certain space activities.

The formation and development of modern entrepreneurship in the field of space exploration and use should be based on the free choice of economic entities to conduct national space activities. The limits of freedom of enterprise should be determined by the specific conditions 
of space activities. The most optimal combination of market self-regulation of space relations of economic entities and public regulation, their interaction and coexistence are of particular significance. Definitely, public regulation of space activity is effective when its permissible limits are determined by the specific conditions of the space market. Usually, public regulation is determined necessary if the market mechanism of self-regulation cannot meet the challenges of sustainable development of space activities. Due to these objective reasons, it is supplemented by effective administrative and legal means of public regulatory influence on the activities of economic entities (licensing, patenting, technical regulation, etc.) (Semenyaka, 2019).

However, the State has a unique role and place in providing legal conditions for the development of national space activities. Commercialization of the results of space activities requires the legal framework first and foremost.

Meanwhile, the strategy of space activity development in Ukraine, public administration of the space industry, and its restructuring should be considerably rethought and improved.

In 2018, the entire property complex of the State enterprise Scientific Production Association Pavlograd Chemical Plant, involved, in particular, in the development, testing and production of components of the launch vehicle, was transferred from the SSA management to the management of the Ministry of Economy (Resolution, 2017). The leading enterprise for space launch system products, SE PA Yuzhmash, made some steps to get out of the re-subordination of the SSA to the Ministry of Economy. Earlier, proposals were made for the merger of Yuzhnnoe SDO and SE PA Yuzhmash by subordination of Yuzhnnoe SDO to SE PA Yuzhmash (Space, 2017), including them in the holding company and others.

Nowadays, the organizational structures and forms of space enterprise management do not comply with the requirements of conditions functioning in the market. Restructuring and corporatization of State-owned space enterprises in order to ensure their productive commercial functioning should be one of the key areas of space industry reform.

The decision to improve and optimize the management of space enterprises should be preceded by the determination of the effectiveness of modern management of State-owned objects in the field of space activity and the mandatory consideration of system-forming sectoral specifics of production and economic activity of space enterprises. In this regard, the analysis and evaluation of the legal effects of relevant legal actions should be under focus to ensure the conservation, development, and efficient use of the existing scientific, technical, industrial and export potential of the space industry.

The mission of the State, which needs an adequate solution, is to provide the legal framework for the most favorable conditions for the implementation of national space activities by entities using legally sound modern methods and means of public regulation.

In the current context, the legislation of Ukraine on space activities requires amendments and additions, considering new space realities and instruments for the development of public relations in the field of space exploration and use (Shemshuchenko \& Semenyaka, 2019), in particular under external aggression of Russian Federation and violation of the territorial integrity of Ukraine (temporary occupation of the Autonomous Republic of Crimea, the city of Sevastopol and military aggression in certain areas of Donetsk and Lugansk regions).

At the present stage, first and foremost improved defense capabilities of the space industry enable to solve the current problems of the national security sector. In other words, the legal prerequisite for ensuring national security and enhancing the State's defense capability is the effective use of the Earth's outer space and the capabilities afforded by modern space activities. In particular, the creation and operation of defense and dual-use space technology (for example, 
spacecraft intelligence) will solve the complex of military-defense missions in the Donbas, will increase the effectiveness of the Armed Forces of Ukraine, will provide effective control over the implementation of the Minsk agreements by the parties, the situation in the ARC. According to the former SSA chairman Pavlo Dehtiarenko, Ukraine should have "its own ears and eyes" in these Ukrainian territories. Therefore, the issues of legal support for the creation and use of appropriate space technology in the interests of the national security and defense sectors also await immediate resolution.

The creation of effective legal conditions for the development of national space activities requires a comprehensive approach to the modernization of Ukrainian space legislation. The use of the "patching of holes" format, as practice illustrates, does not allow to achieve the desired economic and legal result in the field of space activities. It is important to summarize the research outcomes and development of the theory and practice of space law, systematization, and codification of space legislation of Ukraine.

\section{Conclusions}

The successful functioning of an effective mechanism for the legal regulation of modern space relations requires the development of the Concept of Ukrainian law reform on space activities. This document should contain the legal rationale for choosing the optimal behavior model regarding the solution of complex legal problems on the basis of modern space-legal doctrine and practice of space relations. Determination of options for the legal regulation of public relations in the field of national space activity enables to provision new organizational, legal and economic preconditions and mechanisms for ensuring innovative development of space activity in Ukraine will be laid.

However, conceptual foundations for space law should be determined using scientific methods, developments, and achievements of the space law study. Therefore, the development of the Concept should involve highly qualified representatives of academic science, such as legal scholars who are specialists in the field of international and national space law.

\section{References}

Analytical note. Ukrainian-Canadian Space Launch System Cyclone-4M: Ways of creation and expected results. http://dp.niss.gov.ua/public/File/docs/Ciklon\%204M-site.pdf

Convention on International Liability for Damage Caused by Space Objects (1971) November 29. https://zakon.rada.gov.ua/laws/show/995_126

First Ukrainian Space Forum (2018) Visnyk Natsionalnoi akademii nauk Ukrainy, № 10, 87.

Feldman, Vadim (2015) Why did Brazil stay on the space path with Ukraine? Livejournal. https://ukrvpk.livejournal.com/69960.html

Law of Ukraine on amendments to some legislative acts of Ukraine regarding public regulation of space activities (2019) № 1071, November 2, Vidomosti Verkhovnoi Rady Ukrainy, 46, 2019. Art. 300.

Law of Ukraine on space activities (1996) November 15, Vidomosti Verkhovnoi Rady Ukrainy, 1, 1997. Art. 2.

Law of Ukraine on entrepreneurship (1991) February 7, Vidomosti Verkhovnoi Rady Ukrainy, 14, 1991. Art. 168.

Law of Ukraine on insurance (1996) March 7, Vidomosti Verkhovnoi Rady Ukrainy, 18, 1996. Art. 78. 
Lease Agreement of the Baikonur Complex between the Government of the Russian Federation and the Government of the Republic of Kazakhstan (2004) (as amended). December 10. http://base.garant.ru/1153020/

Memorandum of Understanding in the field of peaceful exploration and use of outer space was signed between the State Space Agency of Ukraine (SSA) and the Canadian Space Agency (2018) Ofitsiinyi visnyk Ukrainy, 88, Art. 2948

Order of the Cabinet of Ministers of Ukraine on approval of the Concept of public policy in the field of space activities for the period up to 2032. (2011) № 238-p. Ofitsiinyi visnyk Ukrainy, 84, Art. 1003.

Order of the Cabinet of Ministers of Ukraine on approval of an action plan to address the problematic issues of Space Launch System Cyclone-4 (2017) no. 653-r September 20. https://www.kmu.gov.ua/npas/250287564

Order of the State Space Agency of Ukraine regarding the Space Strategy of Ukraine up to 2022 (2015) No. 100. May 21. https://zakon.rada.gov.ua/rada/show/v0100814-15

Project of National Target Scientific and Technical Space Program of Ukraine for 2019-2023 (2018) http://w1.c1.rada.gov.ua/pls/zweb2/webproc4_1?pf3511=65308

Repartition is cancelled: Why are the SSAU and Yuzhnnoe SDO against secession of Yuzhmash (2019) https://daily.rbc.ua/ukr/show/peredel-otmenyaetsya-pochemu-dkaukb-yuzhnoe-1548924730.html

Resolution of the Cabinet of Ministers of Ukraine on the procedure for issuance (refusal to issue, cancelation) permits for the implementation of certain types of space activities (2020) No. 197 February 26. https://zakon.rada.gov.ua/laws/show/197-2020-\%D0\%BF

Resolution of the Cabinet of Ministers of Ukraine on the transfer of the integral property complex of the State enterprise Scientific Production Association Pavlograd Chemical Plant to the management of the Ministry of Economic Development and Trade (2017) no. 615-r. July 19, Uriadovyi kurier, 171.

Resolution of the Cabinet of Ministers of Ukraine on approval of the procedures and rules for compulsory insurance in the field of space activities (2010) no. 1033 November 10, Ofitsiinyi visnyk Ukrainy, 86. Art. 3034.

Semenyaka, Vasyl (2019) The Current State of Deregulation of Space Activities in Ukraine. Advanced Space Law, 3, 108-119. https://doi.org/10.29202/as1/2019/3/9

Space industry of Ukraine: Transformation processes and their potential effects (2017) https:// yuzhnoye.com/press-center/news/copy_news 76.html

Shemshuchenko, Yuri, and Vasyl Semenyaka (2019) Current status and necessity of reforming space legislation of Ukraine. Chasopys Kyivskoho universytetu prava, 2, 9-16. https:// doi.org/10.36695/2219-5521.2.2019.01

Statistics of launching LV created with the participation of Ukrainian enterprises (2020) http:// www.nkau.gov.ua/ua/launches-of-ukrainian-lv-ua

Strategy of Space Activity of Ukraine for the Period up to 2022: Approved by order of the State Space Lamb (2015) v0100814-15 of 21.05.2015. https://zakon.rada.gov.ua/rada/ show/v0100814-15

Treaty on Principles Governing the Activities of States in the Exploration and Use of Outer Space, Including the Moon and Other Celestial Bodies (1966) December 19. https:// zakon.rada.gov.ua/laws/show/995_480 
Treaty between Ukraine and the Federative Republic of Brazil on long-term cooperation on the utilization of the launch vehicle "Cyclone-4" at the Alcantara Launch Centre (2003) October 21. Ofitsiinyi visnyk Ukrainy, 2004. Art. 3147.

The Ministry of Economy proposes to integrate strategic enterprises into a holding company (2015) https://news.finance.ua/ua/news/-/357686/minekonomiky-proponuye-obyednatystrategichni-pidpryyemstva-v-holdyng

Zheleznyakov, A. (2019) Space activities of the countries of the world in 2019 (Twentieth annual review). http://novosti-kosmonavtiki.ru/news/41837/ 